\title{
A Long Term Field Emissions Study of Natural Gas Fueled Refuse Haulers in New York City
}

\author{
Nigel N. Clark, Byron L. Rapp, Mridul Gautam, \\ Wenguang Wang and Donald W. Lyons \\ West Virginia Univ.
}


The appearance of the ISSN code at the bottom of this page indicates SAE's consent that copies of the papermay be made for personal or intemal use of specific clients. Thisconsent is giver on the condition however, that the copier pay a \$7.00per article copyfee through the Copyright Clearance Center, Inc. Operations Center, 222 Rosewood Drive, Danvers, MA 01923 forcopying beyond thatpermitted by Sections 107 or 108 of the U.S. Copyright Law. This consent does not extend to other kinds of copying such as copying for general distribution, for advertising or promotional purposes, forcreating new collective works, or for resale.

SAE routinely stocks printed papers for a period of three years following date of publication. Direct your orders to SAE Customer Sales and Satisfaction Department.

Quantity reprint rates can be obtainedfrom the Customer Sales and Satisfaction Department.

To requestpermission to reprint a technical paper orpermission to use copyrighted SAE publications in other works, contact the SAE Publications Group.

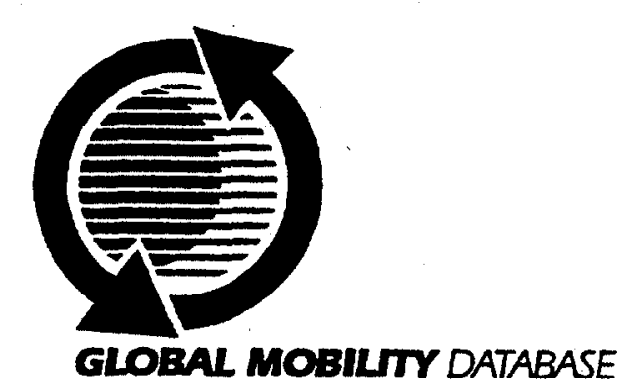

All SAE papers, standards, and selected books are abstractedandindexedinthe SAE GlobalMobility Database.

Nopart of this publication may by reproduced in anyform, in an electronic retrieval system or otherwise, without the prior written permission of the publisher.

\section{ISSN0148-7191}

Copyright 1998 Society of Automotive Engineers, Inc.

Positions and opinions advanced in this paper are those of the author(s) and notnecessarily those of SAE. The author is solely responsible for the content of the paper. A process is available by which discussions will be printed with the paper if it is published in SAE Transactions. For permission to publish this paper in full or in part, contact the SAE Publications Group.

Persons wishing to submitpapers to be consideredfor presentation orpublication through SAE should send the manuscript or 300 word abstract of a proposed manuscript to: Secretary, Engineering Meetings Board, SAE. 


\title{
A LONG TERM FIELD EMISSIONS STUDY OF NATURAL GAS FUELED REFUSE HAULERS IN NEW YORK CITY
}

\author{
Nigel N. Clark, Byron L. Rapp, Mridul Gautam, Wenguang Wang \& Donald W. Lyons \\ West Virginia University
}

Copyright $\bigcirc 1998$ Sociaty of Automotive Engineers, Inc

\section{ABSTRACT}

New York City Department of Sanitation has operated natural gas fueled refuse haulers in a pilot study: a major goal of this study was to compare the emissions from these natural gas vehicles with their diesel counterparts. The vehicles were tandem axle trucks with GVW (gross vehicle eight) rating of 69,897 pounds. The primary use of these hicles was for street collection and transporting the ected refuse to a landfill. West Virginia University Transportable Heavy Duty Emissions Testing Laboratories have been engaged in monitoring the tailpipe emissions from these trucks for seven-years. In the later years of testing the hydrocarbons were speciated for non-methane and methane components. Six of these vehicles employed the older technology (mechanical mixer) Cummins L-10 lean burn natural gas engines. Five trucks were equipped with electronically controlled Detroit Diesel Series 50 lean burn engines, while another five were powered by Caterpillar stoichiometric burn 3306 natural gas engines. The Caterpillar engines employed an exhaust oxygen sensor feedback and three way catalysts. Since the refuse haulers had automatic Allison transmissions. and since they were employed in stop-and-go city service, initial emissions measurements were made using the Central Business Cycle (SAE J1376) for buses. at 42.000 pound test weight. Some additional measurements were made using an ad hoc cycle that has been designed to be more representative of the real refuse hauler use that included several compaction cycles. The Cummins powered natural gas vehicles showed oxides of nitrogen and carbon monoxide emission variations typically associated with variable fuel mixer performance. In the first year of testing, the stoichiometric Caterpillar engines yielded ry low emission levels, but in later years two of these refuse

ers had high carbon monoxide attributed to failure of the - aback system. For example. carbon monoxide on these two vehicles rose from $1.4 \mathrm{~g} / \mathrm{mile}$ and $10 \mathrm{~g} / \mathrm{mile}$ in 1995 to $144.9 \mathrm{~g} / \mathrm{mile}$ and
$57.8 \mathrm{~g} /$ mile in 1996 . These stoichiometric engines were also less fuel efficient than their lean burn counterparts. The Detroit Diesel Series 50 powered refuse haulers produced high levels of oxides of nitrogen. However, it was found that changing the shifting patterns of the transmission lowered the oxides of nitrogen. All three engine types showed the potential for low emissions operation and the particulate matter reduction advantage offered by natural gas was evident from the results.

\section{INTRODUCTION}

The domestic heavy duty fleet is primarily fueled with petroleum derived diesel fuel, and projections are that the domestic consumption of diesel will continue to grow. This decade has seen a move to identify technologies that will permit the heavy-duty fleet to employ alternative fuels, both to reduce imported oil demand and to reduce harmful tailpipe emissions from trucks and buses. Diesel engines are known to be high producers of oxides of nitrogen $\left(\mathrm{NO}_{\mathrm{x}}\right)$ and are usually held to account for almost half of the mobile source $\mathrm{NO}_{\mathrm{x}}$ emissions. The role of $\mathrm{NO}_{\mathrm{x}}$ in the ultimate formation of urban smog is well established. Recently, there has been a groundswell of concern over the hazards to human health associated with ultrafine diesel particulate matter (PM) and it is claimed that modern high pressure injection diesel engines yield a high number count of these ultrafines at and beyond the tailpipe $[1,2]$. In addition, air quality standards now call for the restriction of the mass of particulate matter less than 2.5 microns in size in the atmosphere. This will impact the diesel engine, for it is the highest mobile source PM mass producer [3]. It is clear that transportation will rely in the future either on alternative fuel technologies or the development of systems that provide for a significant reduction in diesel PM and $\mathrm{NO}_{\mathrm{x}}$. Total consumption of alternative fuels, by both the light duty and heavy duty fleets 
was recently estimated at 2.6 percent in 1997 , although the Energy Policy Act of 1992 targets a 30\% alternative fuel usage by 2010 [4]. Further research and development will be essential to insure greater acceptance of alternative fuels throughout the nation.

This paper is concerned with the evaluation of spark ignited natural gas fucled engines employed in heavy duty vehicles in New York City. The engines represented three different technologies from three different manufacturers and in each case diesel control vehicles were available for emissions comparison. An added benefit of this study was that the emissions from this truck fleet were measured on several occasions over a seven-year period. so that a history of emissions performance could be developed.

\section{EMISSIONS TESTING PROGRAM}

The vehicles discussed in this paper were tested under an extensive program to evaluate the emissions benefits of alternative fuels in truck and bus use. Funding is provided by the United States Department of Energy, Office of Transportation Technologies, and emissions testing was performed by West Virginia University in close cooperation with the National Renewable Energy Laboratory and Battelle Memorial Institute. This program has been discussed elsewhere $[5,6]$ and conclusions on alternative fuels use in buses have been published previously [7]. Emissions characterization from the refuse hauler fleet discussed in this paper is now complete.

\section{LITERATURE REVIEW}

The compressed natural gas fueled engines discussed in this paper were all spark ignited. The Caterpillar engines employed a stoichiometric air-fuel mixture and in this regard were similar to most light duty natural gas engines reviewed in the literature $[8,9]$. Stoichiometric operation permits the use of a three way catalyst [10] but a narrow band of air-fuel ratio operation is therefore permissible, and a closed loop fueling strategy, using an oxygen sensor, proves to be essential. The Cummins and Detroit Diesel engines both employed the lean burn principle, which offers benefits in fuel economy and which is often encountered in large bore stationary natural gas engines either with spark or micropilot injection [11]. Lean burn engines can offer low $\mathrm{NO}_{x}$ emissions without after-treatment [10] provided that a sufficiently low fuel/air ratio is maintained. The limit of lean operation is met when misfiring occurs, and efforts are made to enhance ignition to reduce misfiring: even laser ignition has been contemplated to extend the lean limit and reduce $\mathrm{NO}_{x}$ [12]. Fuel effects are known to influence the performance of natural gas engines $[13,14]$ because the gas composition affects the octane number and the fuel energy content, often expressed as the Wobbe number.

Previous research reports have been published which is directly relevant to the use of natural gas engines in heavy duty vehicles. Welliver [15] has reviewed the Cummins natural gas engines in the marketplace in 1996 . Wang et al. [16] reviewed alternative fuel transit bus emissions. including those from buses with early Cummins $L 10$ natural gas engines, and showed that total hydrocarbon (HC) and NOx emissions varied between different buses in the fleet. Additional data were published by Wool et al. [17] while Clark et al. [18] provided a detailed account of the performance of early Cummins natural gas engines with airfuel mixers. and presented new data on emissions from recent electronically controlled Cummins natural gas engines in the field. In the case of $300 \mathrm{hp}$. Cummins L-10 engines operated in line haul tractors. exceptionally low $\mathrm{NO}_{\mathrm{x}}$ emissions were measured [18]. Emissions performance of Detroit Diesel natural gas engine powered buses was presented by Clark et al. [19]: this research showed that the natural gas buses offered the benefit of reducing $\mathrm{NO}_{\mathrm{x}}$ by one third relative to similar diesel buses.

\section{TRANSPORTABLE LABORATORIES}

The West Virginia University Transportable Heavy Duty Vehicle Emissions Transportable Laboratories were constructed to gather emissions data from in-use heavy duty vehicles. The laboratories are fully self-contained units that can be set up at or near the transit agency. Emissions tests are performed at location and returned to the transit agency, usually within one day. Several papers, $[16,20,22]$, have already presented the design of the first of the two laboratories, and emissions data from heavy-duty vehicles fueled by natural gas, methanol and diesel.

The full exhaust from the tailpipe of the test vehicle was ducted to a $45-\mathrm{cm}$ diameter dilution tunnel installed in the emissions trailer. Heated sampling probes carried diluted exhaust to a number of different gas analysis instruments, via heated lines. Levels of carbon dioxide $\left(\mathrm{CO}_{2}\right)$, carbon monoxide $(\mathrm{CO})$, oxides of nitrogen $\left(\mathrm{NO}_{\mathrm{x}}\right)$ and total hydrocarbons (HC) were measured continuously. A gravimetric measurement of particulate matter was obtained using $70 \mathrm{~mm}$ filters, weighed after conditioning for temperature and humidity in an environmental chamber.

Figure 1 shows one of the refuse haulers under test in Brooklyn, New York, 1996. while figure 2 shows the interior of the laboratory trailer. where the filters were weighed and emissions were measured and recorded.

Figure 1: Transportable Laboratory set-up in Brooklyn, New York for the 1996 testing.

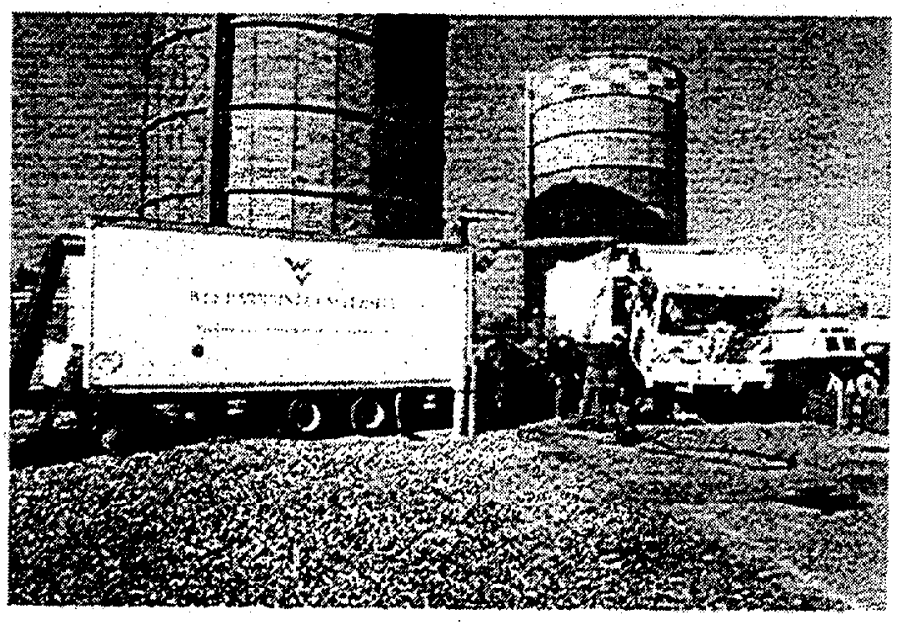


Figure 2: Interior of the laboratory's instrumentation trailer, the data collection center of the laboratory. The full size iilution tunnel can be seen in the upper left of the totograph.

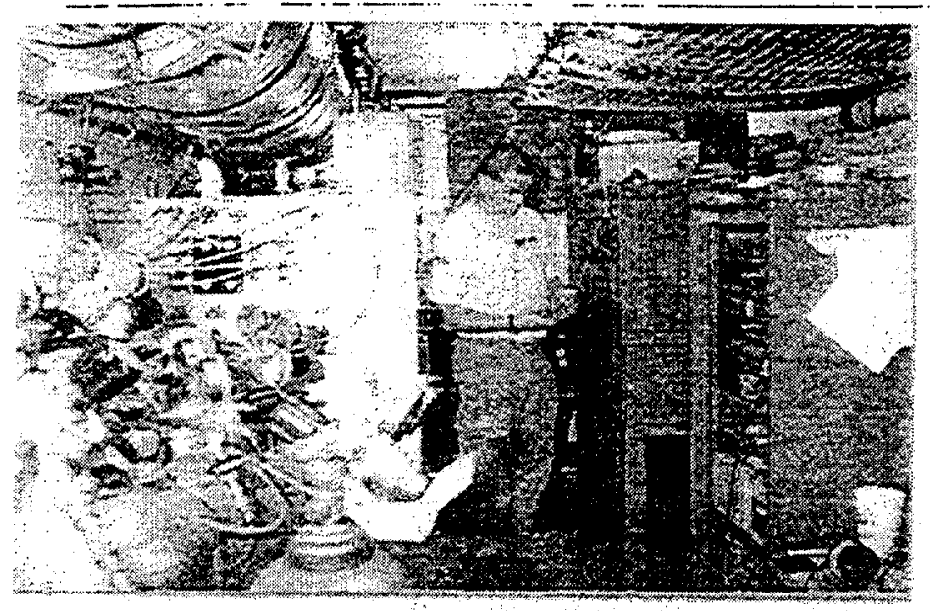

In the later years of this study, bags of diluted exhaust were shipped to West Virginia University for analysis using a Varian 3600 gas chromatograph. The column (J\&W GS-Alumina) used for measurement had an inner diameter of $0.53 \mathrm{~mm}$ and a length of 30 meters. The volume injected was $2 \mathrm{ml}$ and the oven temperature was $40^{\circ} \mathrm{C}$ held for 2.5 minutes, then ramped to $180^{\circ} \mathrm{C}$ at $10^{\circ} \mathrm{C}$ per minute, then held for 15 minutes. A flame ionization detector (FID) was used and the temperature set at $250^{\circ} \mathrm{C}$. Methane and propane undards were used to measure the response factors. Methane sponse was used to quantify methane and propane response was used to quantify all non-methane hydrocarbons. These data were used to distinguish methane from non-methane hydrocarbons in the exhaust and ultimately yield information on the atmospheric reactivity of the exhaust hydrocarbons. No aldehydes were measured in this study.

\section{TEST VEHICLES}

The vehicles in this study were refuse compactors/haulers manufactured by Heil/Crane Carrier Corporation (HCC). Table (1) provides information on these vehicles and the years which testing was preformed. The early 1992 vehicle year models where powered by the mechanically controlled Cummins L-10 260 diesel and the natural gas fueled Cummins L-10 240G (CPL 1379) demonstration engine (non emissions certified), equipped with a catalyst. These engines were connected to a 4 speed automatic transmission (Allison) driving a tandem rear axle. The later 1994 HCC refuse compactors/haulers were powered by CNG fueled Caterpillar 3306 and Detroit Diesel series 50G engines, also by their diesel fueled versions. The 1994 models were also equipped with a 4 speed automatic transmission and the CNG Caterpillar powered vehicles were equipped with a 3-way catalyst. In interpreting the data, the reader should recognize that the Cummins units represent an earlier technology than the Caterpillar or the Detroit Diesel units and that the CPL 1379 Cummins engines were intended for demonstration purposes and were not emissions certified.

\section{TEST DATA}

A complete account of the test dates for each CNG and diesel vehicle is given in Table 1 , together with the average $\mathrm{NO}_{\mathrm{x}}$ data measured on each occasion. Particular attention was paid to $\mathrm{NO}_{\mathrm{x}}$ data since this is the species of most interest in predicting the benefits of CNG in comparison to diesel. The benefit of $\mathrm{CNG}$ in offering far lower PM emissions is already well established $[7,16,18]$ and is reflected in the certification data on record for CNG and diesel engines. In Table 1 the $\mathrm{NO}_{\mathrm{x}}$ data shown are for the vehicles as received on each test occasion. In some instances vehicles were adjusted, tuned or repaired after initial testing and were then re-tested, but this retest data does not appear in Table 1 .

Table 1: Vehicle information, vehiclc number, engine and fuel type, years tested and cycle used with NO emissions by year. Detroit Diesel Corporation (DDC), Caterpillar (CAT.)

\begin{tabular}{|c|c|c|c|c|c|c|c|c|c|c|}
\hline \multirow[t]{2}{*}{ Vehicle Number } & \multirow[t]{2}{*}{$\begin{array}{l}\text { Fuel } \\
\text { Type }\end{array}$} & \multirow[t]{2}{*}{ Engine Type } & \multicolumn{6}{|c|}{$\begin{array}{c}\text { Test year, } \\
\text { NO }_{x} \text {, g/mile CBD }\end{array}$} & \multicolumn{2}{|c|}{$\begin{array}{l}\text { Test year, } \\
\text { NO }_{x}, \text { g/mile } \\
\text { NYGTC }\end{array}$} \\
\hline & & & 92 & 93 & 94 & 95 & 96 & 97 & 96 & 97 \\
\hline $25 \mathrm{CNG} 001$ & CNG & $\mathrm{L}-10240 \mathrm{G}$ & & & 84.9 & 63.1 & 60.1 & & 63.8 & \\
\hline $25 \mathrm{CNG} 002$ & CNG & L-10240G & & 53.6 & & 71.1 & 75.9 & & 88.5 & \\
\hline 25CNG003 & CNG & $\mathrm{L}-10240 \mathrm{G}$ & & & 12.5 & 21.0 & & & & \\
\hline 25CNG004 & CNG & L-10 240G & 90.1 & 56.8 & 45.5 & 48.8 & 105.8 & & 136.3 & \\
\hline $25 \mathrm{CNG} 005$ & $\mathrm{CNG}$ & $\mathrm{L}-10240 \mathrm{G}$ & & & 54.1 & 51.5 & 74.5 & & & \\
\hline 25CNG006 & $\mathrm{CNG}$ & $\mathrm{L}-10240 \mathrm{G}$ & & & 41.7 & 32.3 & 55.1 & & 64.5 & \\
\hline $25 \mathrm{AYX} \times 0 \mathrm{r}$ & Diesel & $\mathrm{L}-10260$ & 38.7 & & 34.3 & 34.5 & 30.1 & & 116.0 & \\
\hline $25 \mathrm{AYX} 602$ & Diesel & $\mathrm{L}-10260$ & & & & 33.5 & 32.1 & & 119.6 & \\
\hline $25 A Y X 603$ & Diesel & $\mathrm{L}-10260$ & & & 34.3 & 37.3 & 34.3 & & 122.4 & \\
\hline $25 \mathrm{CNG} 201$ & CNG & CAT 3306 & & & & 13.5 & 55.9 & 60.4 & 166.5 & 169.1 \\
\hline $25 \mathrm{CNG} 202$ & CNG & CAT 3306 & & & & & 6.3 & & & \\
\hline $25 \mathrm{CNG} 203$ & CNG & CAT 3306 & & & & 2.6 & 11.73 & 9.2 & 94.3 & 94.6 \\
\hline
\end{tabular}


Table 1: (continued) Vehicle information, vehicle number, engine and fuel type, years tested and cycle used with $\mathrm{NO}_{x}$ emissions by year. Detroit Diesel Corporation (DDC), Caterpillar (CAT.)

\begin{tabular}{|c|c|c|c|c|c|c|c|c|c|c|}
\hline \multirow[t]{2}{*}{ Vehicle Number } & \multirow[t]{2}{*}{$\begin{array}{l}\text { Fuel } \\
\text { Type }\end{array}$} & \multirow[t]{2}{*}{ Engine Type } & \multicolumn{6}{|c|}{$\begin{array}{c}\text { Test year, } \\
\mathrm{NO}_{\mathrm{x}}, \mathrm{g} / \text { mile CBD }\end{array}$} & \multicolumn{2}{|c|}{$\begin{array}{c}\text { Test year, } \\
\text { NO }, \text { g/mile } \\
\text { NYGTC }\end{array}$} \\
\hline & & & 92 & 93 & 94 & 95 & 96 & 97 & 96 & 97 \\
\hline $25 \mathrm{CNG} 204$ & CNG & CAT 3306 & & & & 3.4 & 14.6 & 4.6 & 156.6 & 132.9 \\
\hline $25 \mathrm{CNG} 205$ & $\mathrm{CNG}$ & CAT 3306 & & & & 12.7 & $43.8^{*}$ & & $115.5^{*}$ & \\
\hline 25BR216 & Diesel & CAT 3306 & & & & 30.2 & & & & \\
\hline $25 \mathrm{BR} 217$ & Diesel & CAT 3306 & & & & 31.1 & 34.7 & 33.4 & 93.9 & 79.1 \\
\hline 25BR218 & Diesel & CAT 3306 & & & & 29.9 & 31.1 & & 100.7 & \\
\hline $25 B R 232$ & Diesel & CAT 3306 & & & & 33.3 & 31.2 & & 90.2 & \\
\hline 25BR251 & Diesel & CAT 3306 & & & & 29.9 & 32.8 & & 94.3 & \\
\hline 25CNG101 & $\mathrm{CNG}$ & Series $50 \mathrm{G}$ & & & & 70.7 & 28.6 & & 39.5 & \\
\hline $25 \mathrm{CNG} 102$ & $\mathrm{CNG}$ & Series $50 G$ & & & & 66.9 & 46.9 & & 73.7 & \\
\hline $25 \mathrm{CNGl03}$ & $\mathrm{CNG}$ & Series $50 \mathrm{G}$ & & & & 64.9 & 56.6 & 58.6 & 86.2 & 79.64 \\
\hline $25 \mathrm{CNG} 104$ & $\mathrm{CNG}$ & Series $50 \mathrm{G}$ & & & & 69.9 & 61.6 & 19.8 & 105.8 & 29.0 \\
\hline $25 \mathrm{CNG} 105$ & $\mathrm{CNG}$ & Series $50 \mathrm{G}$ & & & & 75.8 & 79.5 & 64.1 & 99.7 & 96.2 \\
\hline 25BR609 & Diesel & Series 50 & & & & 35.5 & 48.8 & & 141.3 & \\
\hline 25BR610 & Diesel & Series 50 & & & & 36.1 & & & & \\
\hline 25BR615 & Diesel & Series 50 & & & & 34.1 & & 42.6 & & 120.3 \\
\hline $25 \mathrm{BR} 616$ & Diesel & Series 50 & & & & 34.1 & 36.0 & & 111.1 & \\
\hline 25BR716 & Diesel & Series 50 & & & & 41.5 & & & & \\
\hline
\end{tabular}

All of the subject test vehicles, bar one, were tested in 1995 in Brooklyn, NY, so that data from this year were chosen to enter the discussion. Figure 3 provides a histogram of data comparing the emissions from six Cummins L10 CNG and three Cummins $\mathrm{L} 10$ diesel powered vehicles, tested through the CBD cycle at $42,000-\mathrm{lb}$. test weight. Each vehicle was tested several times, and the average of those tests was used in preparing this plot. The CNG vehicles showed a convincing reduction in PM, but were less satisfactory than the diesel powered vehicles in gaseous emissions levels. The causes for these high emissions have been reviewed by Clark et al.[18]. High $\mathrm{CO}$ emissions from the $\mathrm{CNG}$ vehicles can be attributed to a rich idle condition, while high $\mathrm{NO}_{\mathrm{x}}$ emissions were most likely caused by insufficiently lean operation under load. The higher HC emissions do not represent a cause for concern, since the bulk of the $\mathrm{HC}$ emissions were methane, which is not believed to contribute to smog formation. The variation of emissions between the Cummins CNG powered vehicles was noteworthy. The highest $\mathrm{NO}_{\mathrm{x}}$ emitter yielded a value of $71.1 \mathrm{~g} / \mathrm{mile}$ (higher than a typical diesel vehicle), but the lowest yielded $21.0 \mathrm{~g} / \mathrm{mile}$ (lower than a typical diesel vehicle). The lowest $\mathrm{CO}$ emitting CNG Cummins powered truck in 1995 produced $1.3 \mathrm{~g} / \mathrm{mile}$, while the highest produced $49.1 \mathrm{~g} / \mathrm{mile}$. These variations are caused by differences in the air/fuel ratios and are typical of the operation of the carly mixer-type engines. The benefits of adjusting the mixers to produce the desired air/fuel ratio have been supported by data in reference [18].

Figure 4 presents the corresponding 1995 data for the Detroit Diesel Series 50 powered vehicles. Comparisons between the CNG and diesel vehicles were similar to those for the Cummins vehicles. PM was lower for the CNG operation, but $\mathrm{CO}, \mathrm{NO}_{\mathrm{x}}$ and total $\mathrm{HC}$ levels were higher. The DDC
CNG control system, although electronic, employed an open loop fueling control philosophy. The air/fuel mixture was most likely insufficiently lean or the spark timing insufficiently retarded to reduce the $\mathrm{NO}_{\mathrm{x}}$ emissions. The choice of spark timing has to cater to the $\mathrm{NO}_{\mathrm{x}}$-cfficiency tradeoff. In contrast to the Cummins powered CNG vehicles, the DDC CNG vehicles showed little variation in $\mathrm{NO}_{\mathrm{x}}$ between vehicles, which bore testimony to the ability of the electronically controlled fueling system to maintain air/fuel ratios that were repeatable from one vehicle to the next. Testing with the DDC vehicles drew attention to a concern in using the $C B D$ cycle to characterize emissions. In some cases, the vehicle's transmission automatic shift point was close to $20 \mathrm{mph}$ under cruise conditions, and it was found that emissions in the higher or lower gear could differ substantially.

Data from the Caterpillar engine powered refuse haulers are shown in Figure 5. It is evident that the closed loop stoichiometric operation, combined with a 3-way catalyst, has the potential to yield very low emissions for $\mathrm{CNG}$ operation. PM was at low levels, while $\mathrm{NO}_{\mathrm{x}}$ levels were at one fourth those for the diesel vehicles. Although $\mathrm{CO}$ was higher for the Caterpillar CNG engines than for their diesel counterparts, the difference between fuels was more modest than in the case of the lean burn vehicles discussed above. Both $\mathrm{HC}$ and $\mathrm{CO}$ emissions from these stoichiometric CNG engines were lower than those from the lean burn engines discussed above, which supports the argument that the closed loop fueling controls and the catalyst activity levels were operating in a satisfactory fashion during the 1995 emissions testing. A disadvantage of stoichiometric operation is that fuel consumption is typically poor under load conditions. 
Variation over seven years of testing of the emissions - for one of the Cummins powered CNG vehicles is shown in igure 6. This level of variation could be expected for mixere fuel introduction, where there are no capacities to ...ount for gas quality variations, changing atmospheric conditions or wear of mixer components. The relationship between $\mathrm{NO}_{\mathrm{x}}$ and air/fuel ratio is so non-linear in the lean region (at lambda ratios between 1.2 and 1.6) that small changes in mixer performance can yield substantial changes in the emissions level. This data echoes the conclusion of reference [18] that frequent air/fuel ratio adjustments are important in maintaining low emissions levels from these early Cummins CNG engines.

Data on the variation from year to year of emissions from the DDC CNG vehicles yields mixed conclusions. Figure 7 provides some relevant data. For one of the vehicles reviewed in Figure 7 , the $\mathrm{NO}_{x}$ emissions changed little from year to year, but for the other, a significant reduction was seen in the last year in which this vehicle was tested. There was sufficient concern over this drop in $\mathrm{NO}_{\mathrm{x}}$ that this vehicle was re-tested during the third year, when similarly low values for $\mathrm{NO}_{\mathrm{x}}$ emissions were found.

Variation of the emissions of two of the Caterpillar powered CNG fueled trucks over the years of testing is shown in figure 8. It is evident that one of the trucks maintained low emissions during the second year of testing, but that the emissions on the other truck rose dramatically.

The authors concluded that the closed-loop-fueling ? might be at fault, perhaps due to an oxygen sensor

function. Slightly rich operation will cause a noticeable increase in $\mathrm{NO}_{\mathrm{x}}$ emissions, for which the catalytic converter cannot compensate. This point is illustrated with some continuous data from a third Caterpillar powered truck, not presented in Figure 8. Figure 9 shows the instantaneous emissions rate of $\mathrm{NO}_{\mathrm{x}}$ from this third truck as tested in 1995. when the $\mathrm{NO}_{\mathrm{x}}$ emissions averaged to a low value of 3.43 $\mathrm{g} / \mathrm{mile}$ on the CBD cycle. Only the first two peaks of the CBD cycle yielded appreciable $\mathrm{NO}_{\mathrm{x}}$ and these peaks correspond to the catalyst warm-up period. When this vehicle was re-tested in 1996, the $\mathrm{NO}_{\mathrm{x}}$ emissions retained high, irregular peaks throughout the cycle, as shown in Figure 10. While it could be argued that the reducing catalyst had become partly deactivated, it is more likely that the air/fuel ratio control was imprecise, since the continuous $\mathrm{NO}_{x}$ emissions do not follow the vehicle load closely.

\section{EFFECT OF CYCLES}

All of the data discussed above were taken using the CBD cycle. but it was recognized that this cycle, originally intended for buses, did not represent fairly the operation of the refuse haulers. Without performing a detailed study, WVU researchers sought to develop an ad hoc cycle that presented more reasonably the actual truck use. Refuse

rs were followed in Morgantown, West Virginia and then in New York City, New York. Behavior and duty cycles were noted and in addition some data were acquired from one of the Detroit Diesel powered units in New York City using a speed and pedal position data logger. It was found that the drivers seldom used full power during acceleration from pickup point to pickup point, that vehicle speed and distance traveled was low and that refuse compactions should be considered in the cycle. The resulting test cycle, termed. perhaps ungraciously, the "New York Garbage Truck Cycle" (NYGTC), incorporated three compactions, one acceleration to $20 \mathrm{mph}$, two acceleration bursts to $12.5 \mathrm{mph}$, and four bursts to $5.5 \mathrm{mph}$, most of the cycle time was spent idling. only 0.38 miles are covered in one cycle. Figure 11 shows the speed-time trace and the three compaction sequences included in the cycle.

The NYGTC yields high emissions levels in units of $\mathrm{g} / \mathrm{mile}$, due to the short distance and is best compared with measurements from the CBD cycle in units of g/diesel gallon equivalent of fuel. In this research, 1 gallon of diesel was equated with 137 standard cubic feet of natural gas. Fuel consumption was inferred from exhaust emissions levels with assumed values of carbon to hydrogen ratio in the fuel. Figure 12 compares the $\mathrm{CO}$ and $\mathrm{NO}$ emissions between the two cycles. The cycle specific and engine specific effects on the emission in gram/gallon are evident in figure 12. In the case of $\mathrm{NO}_{\mathrm{x}}$ levels, both lean burn engines yield lower emissions on the NYGTC than the CBD, because the NYGTC has less high power demand on the vehicle. However, this was not the case with the Caterpillar powered vehicle, where the level rose by a factor of four for the NYGTC over the CBD. In contrast, the $\mathrm{CO}$ emissions for the Caterpillar powered vehicles emissions were higher. The Detroit Diesel Series $50 \mathrm{G}$ emissions of $\mathrm{CO}$ were slightly lower on the NYGTC. Data of this kind raises concerns in the translation of vehicle emissions measurements into inventory predictions, based simply on "vehicle miles traveled" (VMT). Clearly the vehicle vocation can have a profound effect on the emissions levels, regardless of the units used.

\section{HYDROCARBON COMPOSITION}

Total hydrocarbons were proportioned between methane $\left(\mathrm{CH}_{4}\right)$ and non-methane hydrocarbons (NMHC). Non-methane hydrocarbons consist of some unburned higher hydrocarbons present in the original fuel gas, and also some products of partial combustion, such as ethene (ethylene) [14]. Table 2 shows the flame ionization detector (FID) values (representing total HC measured in the field) along with methane and NMHC values for the 1996 year of testing, for the Cummins, Caterpillar and DDC powered CNG vehicles. Ironically, there was larger difference in the $\mathrm{NMOG} / \mathrm{CH}_{4}$ ratio between the two lean burn types than the Detroit Diesel and Caterpillar engine values. It is difficult to identify precise causes for the data trends: catalyst selectivity. cylinder-to-cylinder air/fuel ratio variations, spark-timing and average air/fuel ratio will affect the nature of hydrocarbons emitted. 
Table 2: 1996 Average hydrocarbon emission data from three engine types, measured using the CBD cycle. DDC and Cummins data have been averaged to contrast lean burn with stoichiometric operation.

\begin{tabular}{|l|c|c|c|c|}
\hline Engine Type & $\begin{array}{c}\text { FID } \\
\text { total HC. } \\
\text { gram/mile }\end{array}$ & $\begin{array}{c}\mathrm{CH}_{4} \\
\text { gram/mile }\end{array}$ & $\begin{array}{c}\text { NMOG } \\
\text { gram/mile }\end{array}$ & $\% \mathrm{NMOG} / \mathrm{CH}_{4}$ \\
\hline Caterpillar (stoichiometric) & 24.36 & 21.84 & 1.45 & $6.64 \%$ \\
\hline DDC (lean bum) & 10.85 & 9.75 & 0.6 & $6.34 \%$ \\
\hline Cummins (lean burn & 13.41 & 11.97 & 1.1 & $9.19 \%$ \\
\hline DDC + Cummins average & 12.13 & 10.86 & 0.85 & $7.82 \%$ \\
\hline
\end{tabular}

\section{CONCLUSIONS}

Data from a seven-year study of emissions from CNG and diesel powered refuse haulers in New York City have shown that the CNG powered vehicles offer an undisputed advantage in the reduction of mobile source PM. However, in general, the lean burn CNG vehicles did not exhibit an advantage in emissions of $\mathrm{NO}_{\mathrm{x}}$. This conclusion is in contrast to two recently published studies of natural gas powered trucks and buses. In one of those studies [19], Detroit Diesel natural gas Series 50G powered transit buses returned $\mathrm{NO}_{\mathrm{x}}$ emissions levels one-third lower than their diesel powered control buses. In the other study [18], state of the art Cummins L10 lean burn closed loop natural gas engines were contrasted with diesel Cummins M1l engines. In an application in line haul tractors, using liquefied natural gas, these engines returned natural gas $\mathrm{NO}_{\mathrm{x}}$ levels at one sixth of the diesel $\mathrm{NO}_{\mathrm{x}}$ levels, although natural gas $\mathrm{CO}$ levels were higher than for the diesel. Also, in [18], similar CNG fucled Cummins engines used in transit buses offered lower emissions levels of both $\mathrm{CO}$ and $\mathrm{NO}_{x}$ compared with their diesel fueled counter-parts. This data, coupled with reports by Kubesh and Podnar [23] of ultra-low emissions levels from a prototype closed loop lean burn natural gas engine, prove conclusively that it is the engine management strategy far more than the fuel which determines the ability to reduce tailpipe emissions. It is conceded that the Cummins engines discussed in the present paper employed far less sophisticated controls than the advanced engines discussed in references $[18,19]$. Data gathered in the present study from stoichiometric Caterpillar natural gas engines showed their ability to produce very low levels of $\mathrm{CO}$ and $\mathrm{NO}_{x}$, but re-tests after a year of service showed higher emissions due to possible fueling feedback control failure.

This research highlighted the importance of maintenance and adjustment in deploying natural gas fueled engines. particularly those with mixer-type fueling. Year to year emissions variations supported this conclusion. In addition. the dependence of emissions on the cycle used was confirmed. This reinforces the authors' belief that the simple product of "vehicle miles traveled" with emissions factors may prove inaccurate for emissions inventory purposes.

\section{ACKNOWLEDGEMENTS}

Funding for the CNG powered New York City refuse hauler study was provided by the U.S. Dept. of Energy, Office of Transportation Technologies. The authors are grateful to the engine and emissions research staff at WVU and acknowledge the role of James Kopasko and Wenwei Xie in the development of the NYGTC. Timothy Harte of the New York City Dept. of Sanitation was a valuable supporter of this study.

\section{REFERENCES}

1. Bagley, S.T., K .J. Baumgard, L. D. Gratz, J. H. Johnson, and D. G. Leddy, "Characterization of Fuel and Aftertreatment Device Effects on Diesel Emissions", Health Effect Institute, Research Report Number 76, September 1996.

2. Ferin, G. O., Penny, D. P., "Pulmonary Retention of Ultrafine and Fine Particles in Rats", Am. J. Respir. Cell Mol. Biol, Vol. 6 pp. 534-542, 1992.

3. "Air Quality Criteria for Particulate Matter" EPA, Vol. $1,1996$.

4. Alternative Fuels Task Force, "Alternative Transportation Fuels a Comparative Analysis", AIChE Commentary, September 1997.

5. Chandler, K., Malcosky, N., Motta, R., Norton. P.. Kelly, K., Schumacher, L. and Lyons, D. W., "Alternative Fuel Transit Bus Evaluation Program Results", SAE Paper 961082, 1996.

6. Chandler, K. J., Norton, P.. Clark, N. N.. "Preliminary Results from NREL's Alternative Fuel Truck Evaluation Project", SAE Paper 981392, 1998. 
7. Chandler, K. L., Malcosky, N. D., Motta, R. C., Kelly, K. J.. Norton, P. M., and Schumacher, L. G. "Final Alternative Fuel Transit Bus Evaluation Results" Battelle 505 King Avenue Columbus. Ohio, December 1996.

8. Tennant. C. J., Atkinson. R. J., Traver, M. L., Atkinson. C. M., and Clark. N. N., "The Design of a Bi-Fuel Engine Which Avoids the Penalties Associated with Natural Gas Operation.". SAE Paper 950679. 1995.

9. Liss, W. E., Thrasher, W. H., "Natural Gas as a Stationary Engine and Vehicular Fuel" SAE Paper 912364. 1991.

10. Heck. R. M., Farrauto, R. J., "Catalytic Air Pollution Control", Van Nostrand Reinhold

11. Chrisman, B. M.. Callahan, T. J., Chiu, J. P., "Investigation of Micro Pilot Combustion in a Stationary Gas Engine", ICE-Vol. 30-3, 1998.

12. Ma. J. X., Ryan, T. W. III, Buckingham, J. P., "Nd: YAG Laser Ignition of Natural Gas" Southwest Research Institute, ICE 98-ICE-114, Vol. 30-3, 1998.

13. Raina, A., Midkiff, C. K., Bell, S. R., and Carl, D. "Characterization of the Effects of Methane and Propane Mixtures on Performance and Emissions in a Spark-Ignited Engine" Paper No. 98-ICE-108 ICE vol. 30-3, 1998.

14. Clark, N. N., Mott. G. E., Atkinson, C. M., deJong, R. J., Atkinson, R. J., Latvakosky, T., and Ytaver, M. L. "Effect of Fuel Composition on the Operation of a Lean Burn Natural Gas Engine" SAE Paper 952560, 1995.

15. Welliver, D. R., "Cummins Heavy Duty Naturakl Gas Engine Products" DOE/GO-10096-315, DE96013100, 1996 Windsor Workshop.

16. Wang, W., Gautam, M., Sun, X., Bata, R., Clark, N., Palmer, M. G., and Lyons, D., "Emissions Comparisons of Twenty-Six Heavy Duty Vehicles Operated on Conventional and Alternative Fuels" SAE Paper 932952, 1993.

17. Wool, W., Jackson, M. and Bassett, T., "An Evaluation of Compresses Natural Gas Buses in Small Transit Operations." SAE Paper 960769. 1996.

18. Clark, N. N., Lyons, D. W., Rapp, B. L., Gautam, M., Wang, W., Norton, P., White. C. L., and Chandler, K. L., "Emissions from Trucks and Buses Powered by Cummins L-10 Natural Gas Engines", SAE Paper 981393, 1998.
19. Clark, N. N., Gautam, M., Lyons, D. W., Bata, R. M., Wang, W. Norton, P., and Chandler, K. " "Natural Gas and Diesel Transit Bus Emissions: Review and Recent Data." SAE Paper 973203, 1997.

20. Clark, N. N., Gadapati, C. J., Kelly, K., White, C. L., Lyons, D. W., Wang, W., Gautam. M. and Bata. R., "Comparative Emissions from Natural Gas and Diesel Buses". SAE Paper 952746, 1995.

21. Clark. N. N., Gautam, M., Bata, R. M., and Lyons, D. W. , "Design and Operation of a New Transportable Laboratory for Emissions Testing of Heavy Duty Trucks and Buses", Int. Journal of Vehicle Design: Heavy Vehicle Systems, Vol. 2, Nos. 3/4, pp. 285-299, 1995.

22. Bata, R., Lyons, D. W., Clark, N., Gautam, G. and Wang, W. , "Vehicle Performance and Exhaust Gas Emissions of In-use Methanol Fueled Transit Buses", Eleventh International Symposium on Alcohol Fuels, April 1996, Sun City, South Africa, Vol. 3, pp. 809$820,1996$.

23. Kubesh, J. T. and Podnar, D. J. "Ultra Low Emissions from an On-Highway Natural Gas Engine" SAE 981394, 1998. 
Figure 3: 1995 emissions average comparison of Cummins L-10 powered refuse haulers fueled by natural gas and diesel. (CBD cycle)

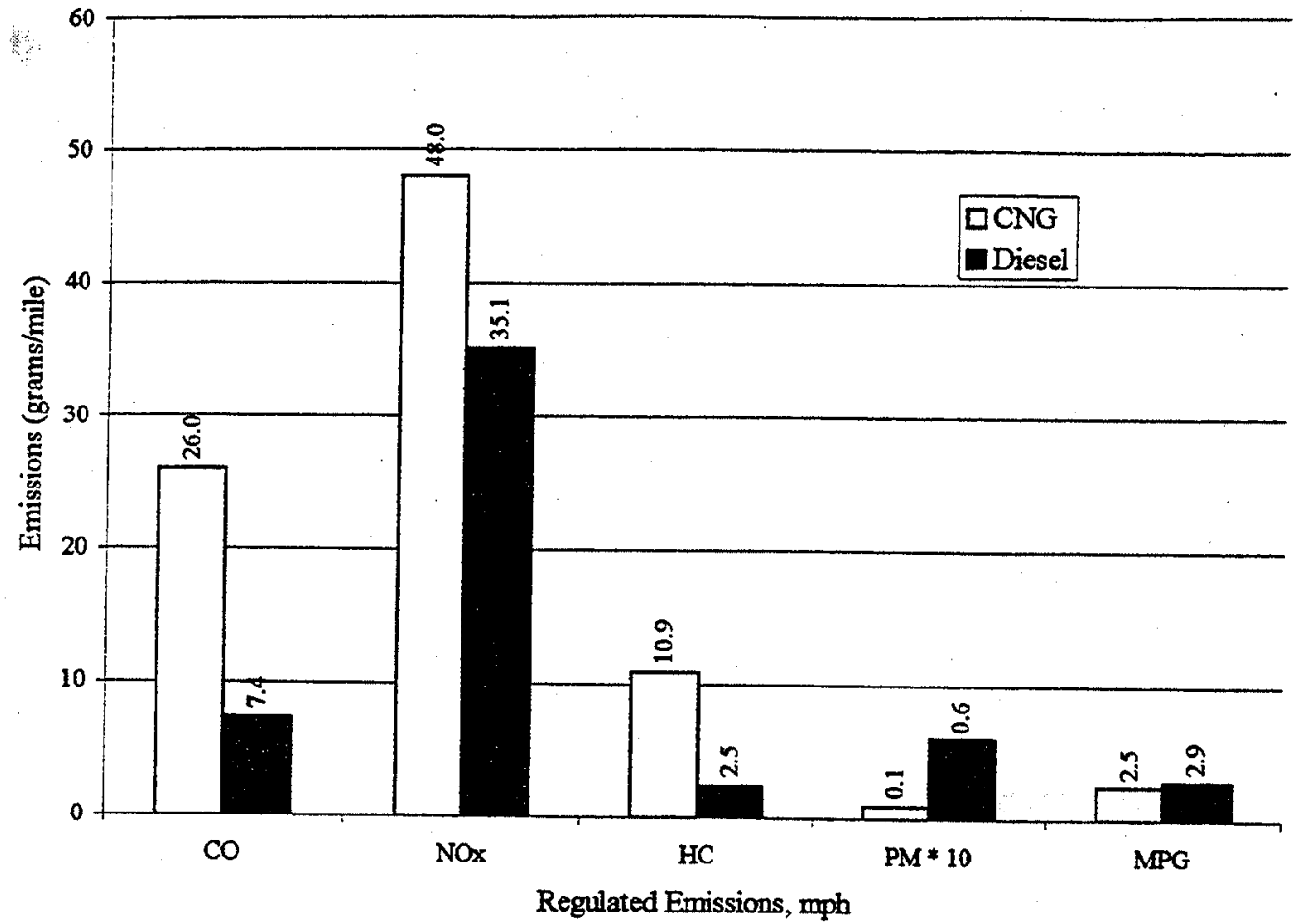

Figure 4: 1995 emissions average comparison of Detroit Diesel Series 50 powered refuse haulers fueled by natural gas and diesel. (CBD cycle)

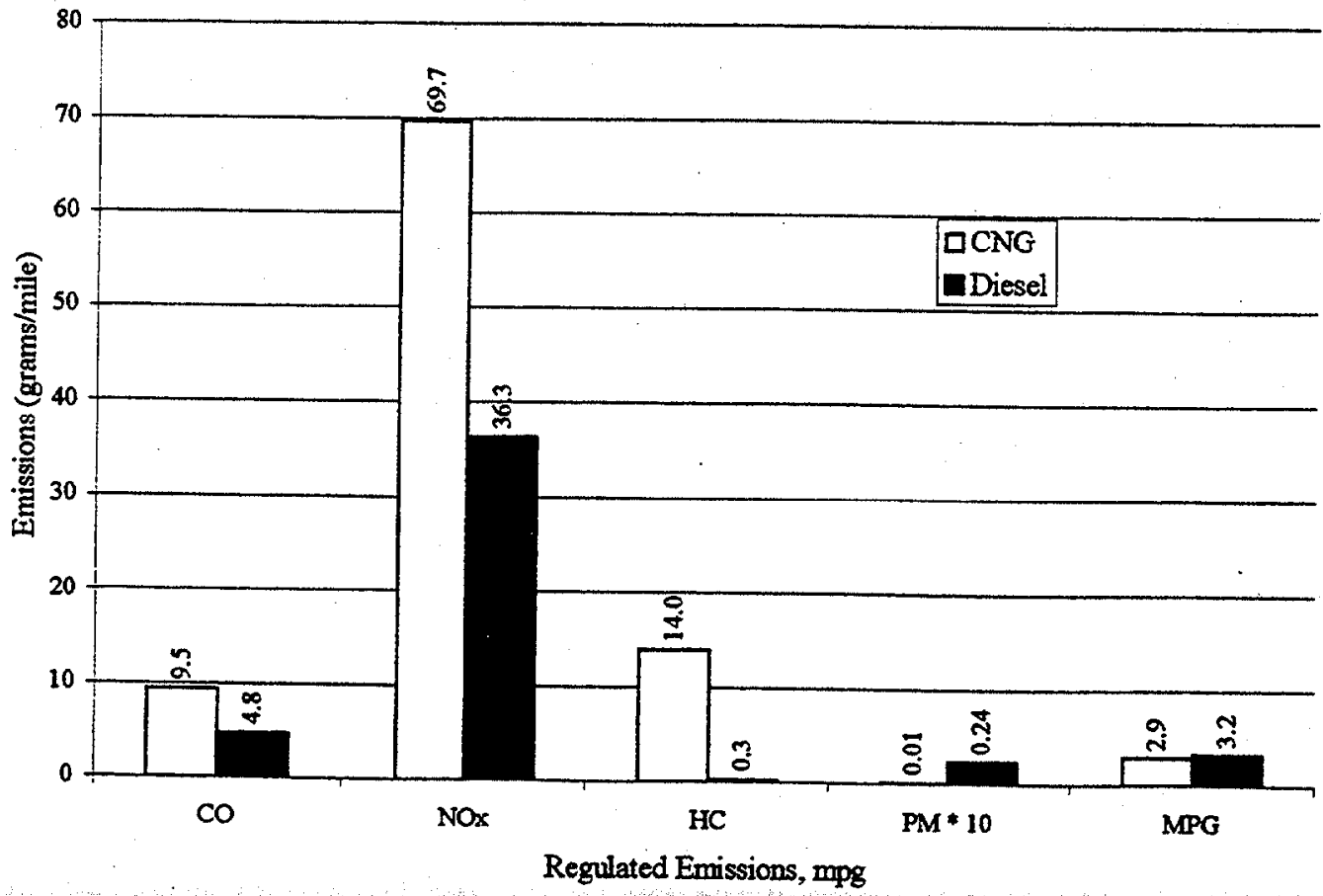


Figure 5: 1995 emissions average comparison of Caterpillar 3306 powered refuse haulers fueled by natural gas and diesel. (CBD cycle)

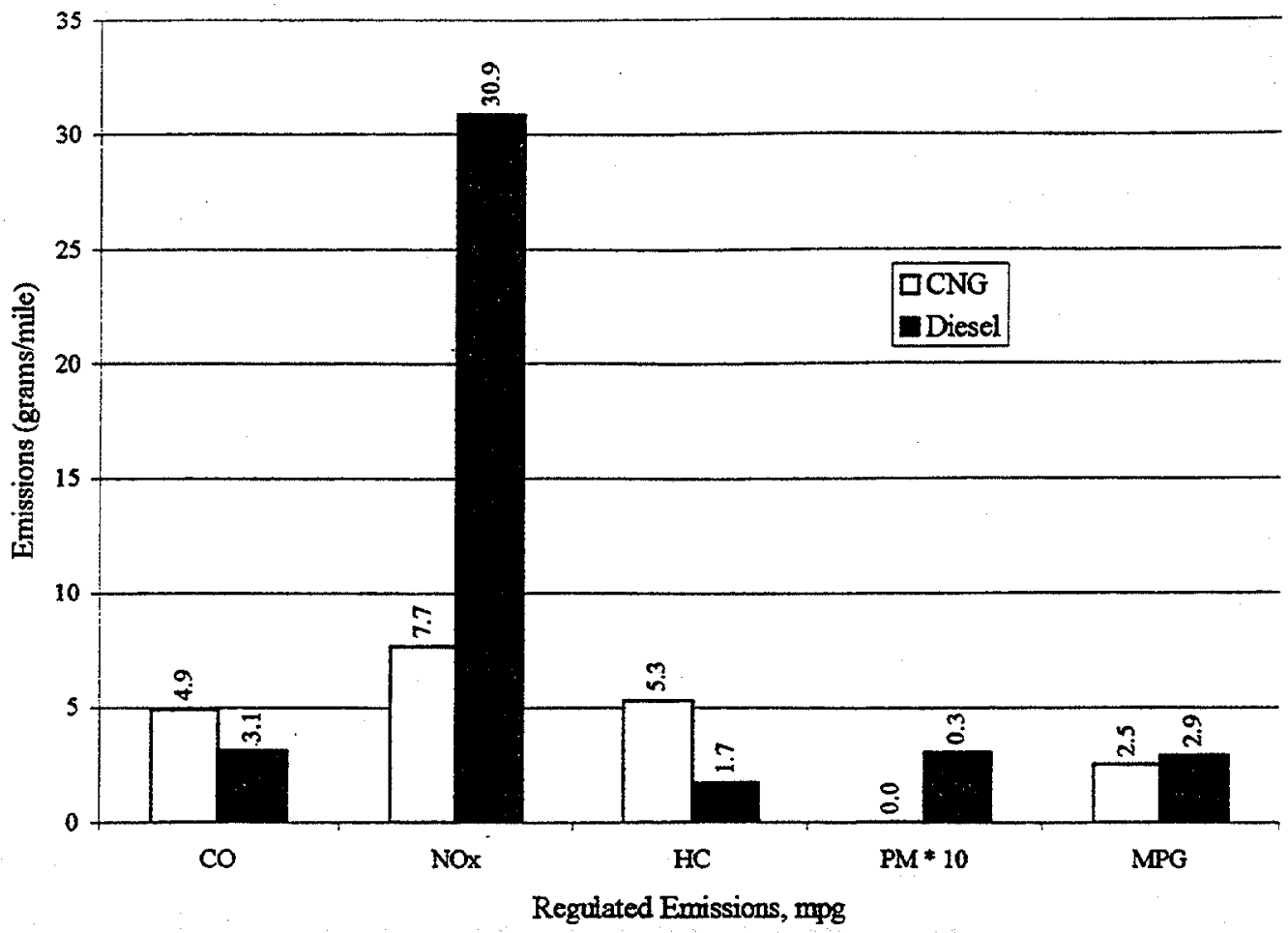

Figure 6: Five years of emissions data on refuse hauler $\# 25 C N G 004$, powered by a Cummins L-10 engine fueled with natural gas. (CBD cycle)

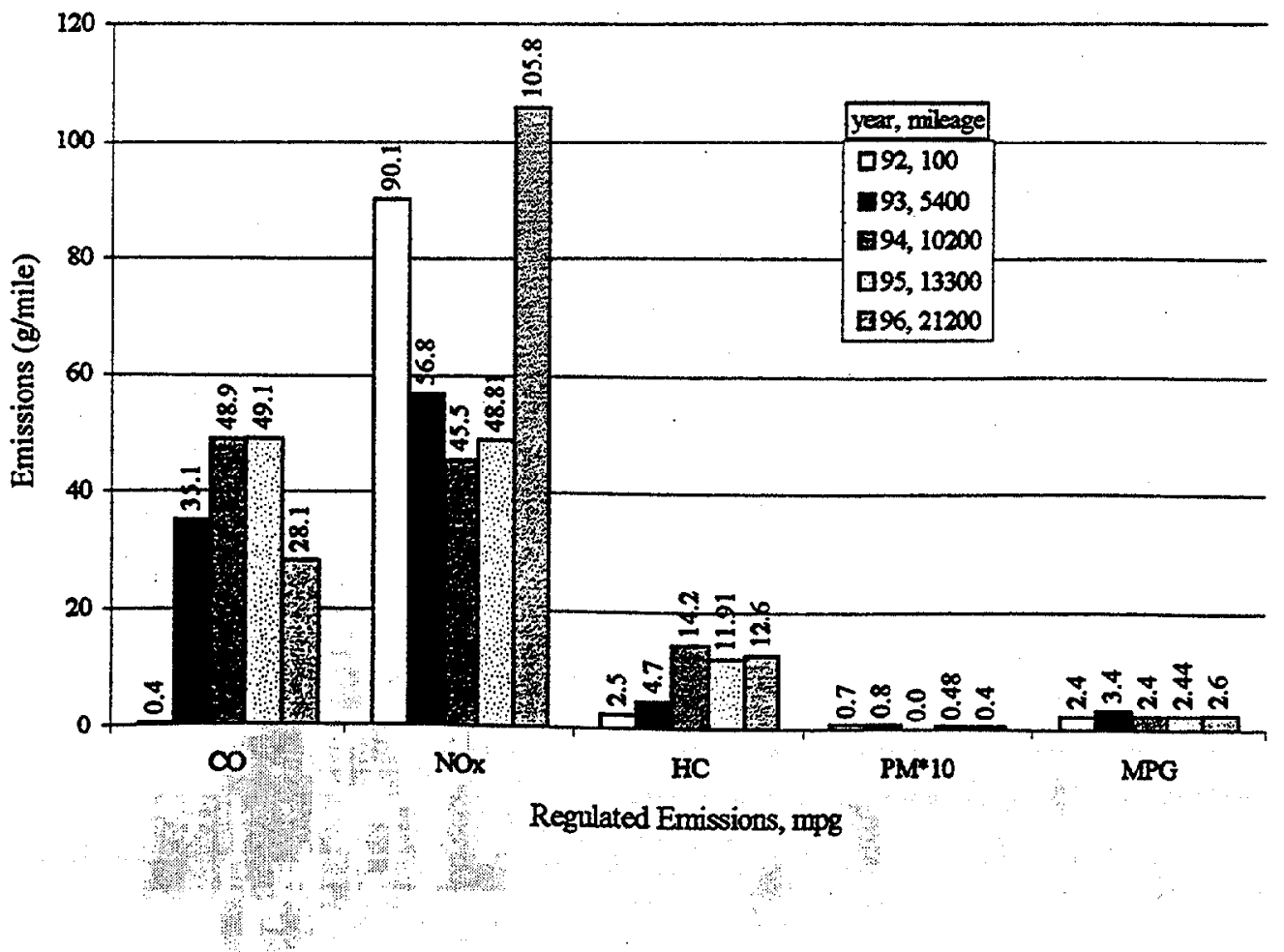


Figure 7: $1995-1997$ emissions data from two refuse haulers powered by Detroit Diesel Series 50s, fueled with CNG. (CBD cycle)

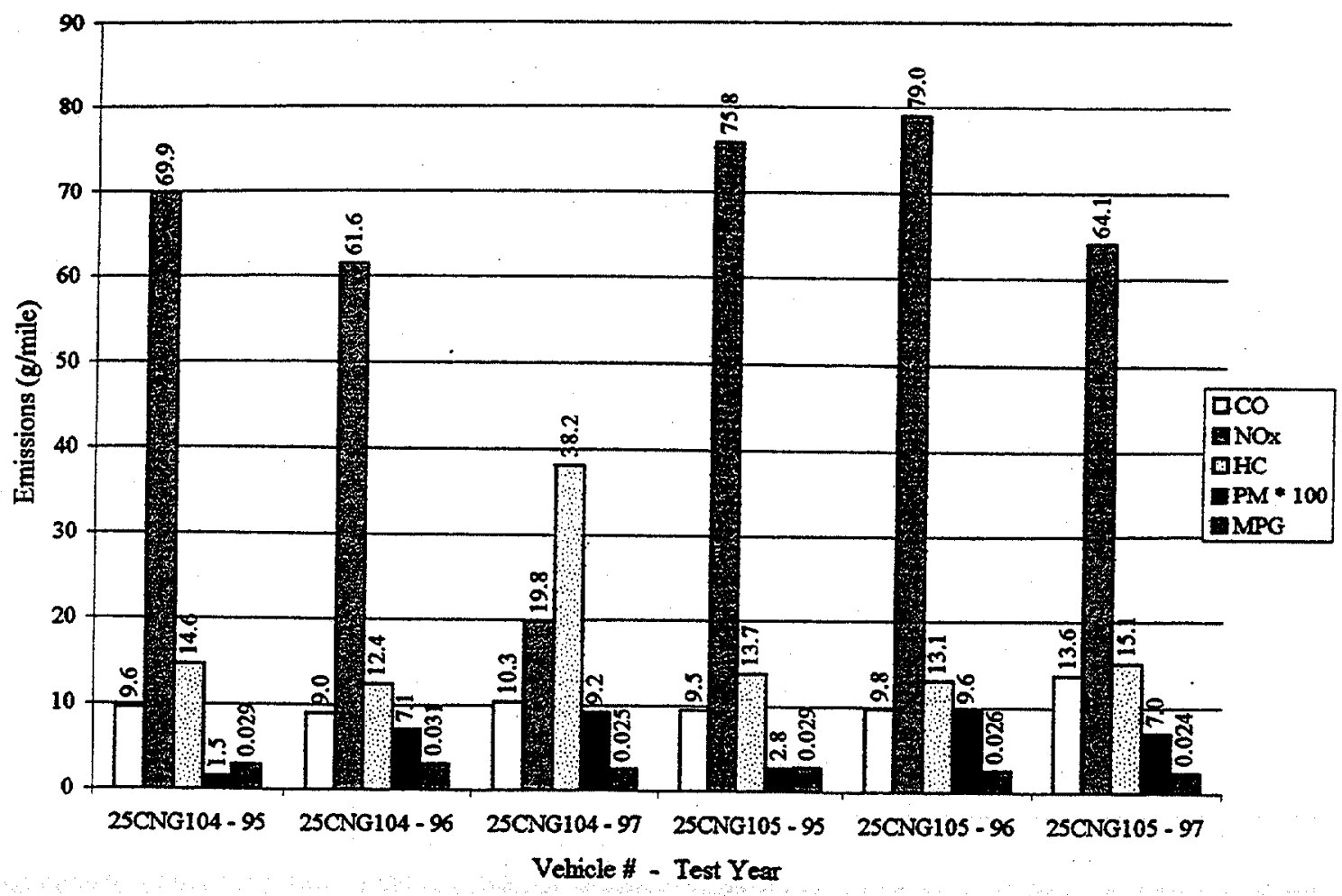

Figure 8: 1995 - 1997 emissions data from two refuse haulers powered by Caterpillar engines, fueled with CNG. (CBD cycle)




Figure 9: 1995 continuous $\mathrm{NO}_{x}$ data collected from refuse hauler \#25CNG204, powered by a Caterpillar 3306 engine, fueled with CNG. (CBD cycle)

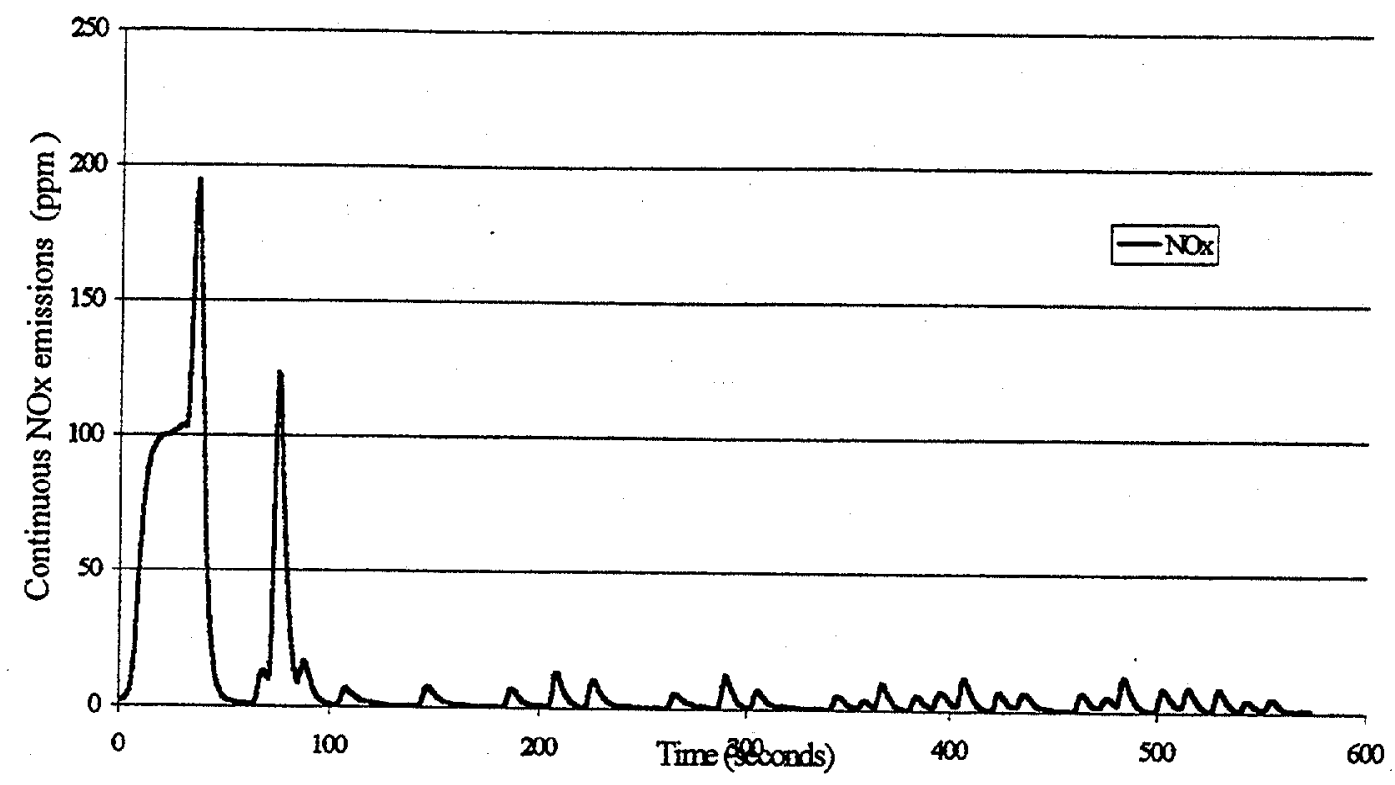

Figure 10: 1996continuous $\mathrm{NO}_{\mathrm{x}}$ data collected from refuse hauler \# 25CNG204, powered by a Caterpillar 3306 engine, fueled with CNG. (CBD cycle)

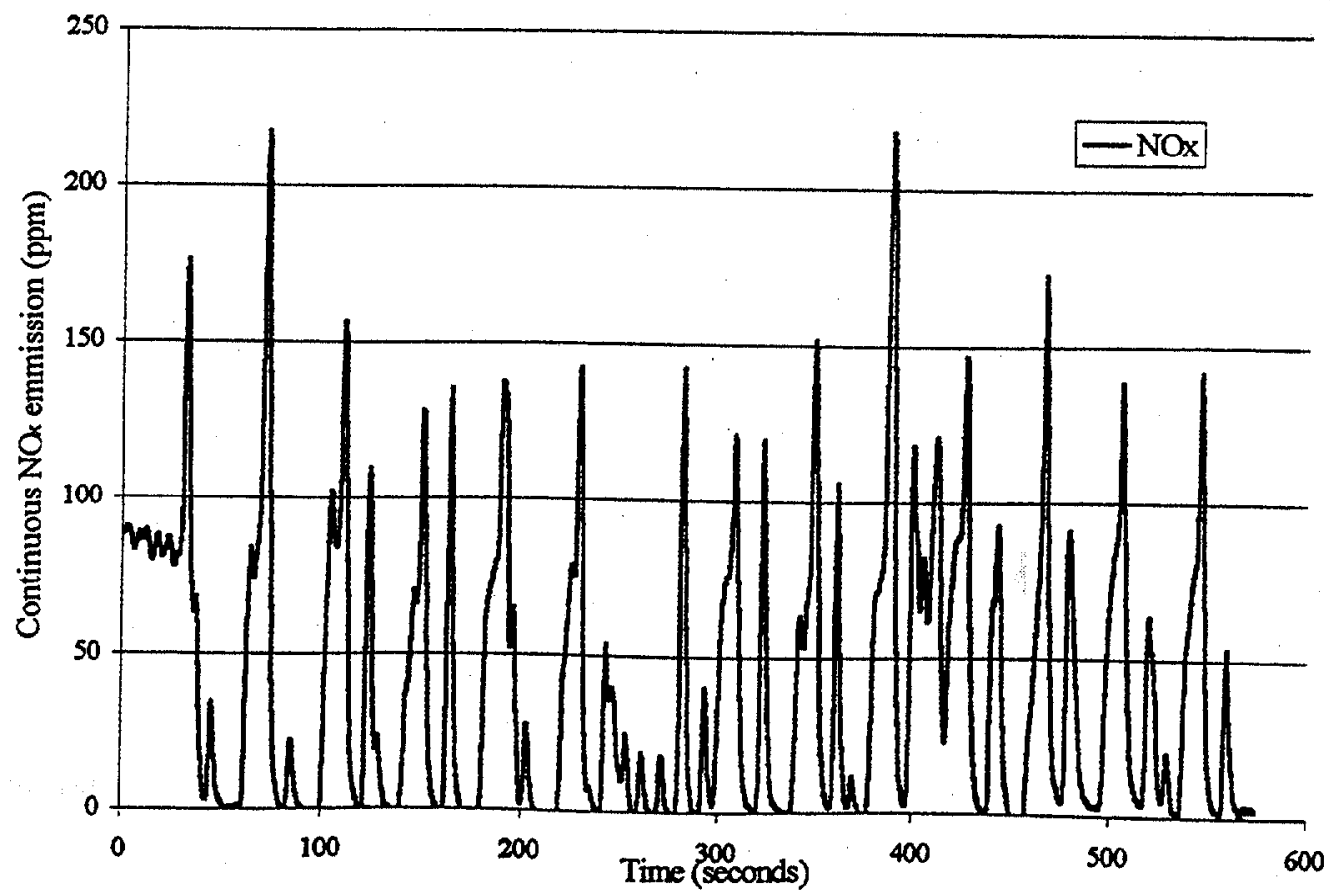


Figure 11: Speed vs. time trace of the New York Garbage Truck Cycle (NYGTC) with compaction, total distance traveled 0.38 miles

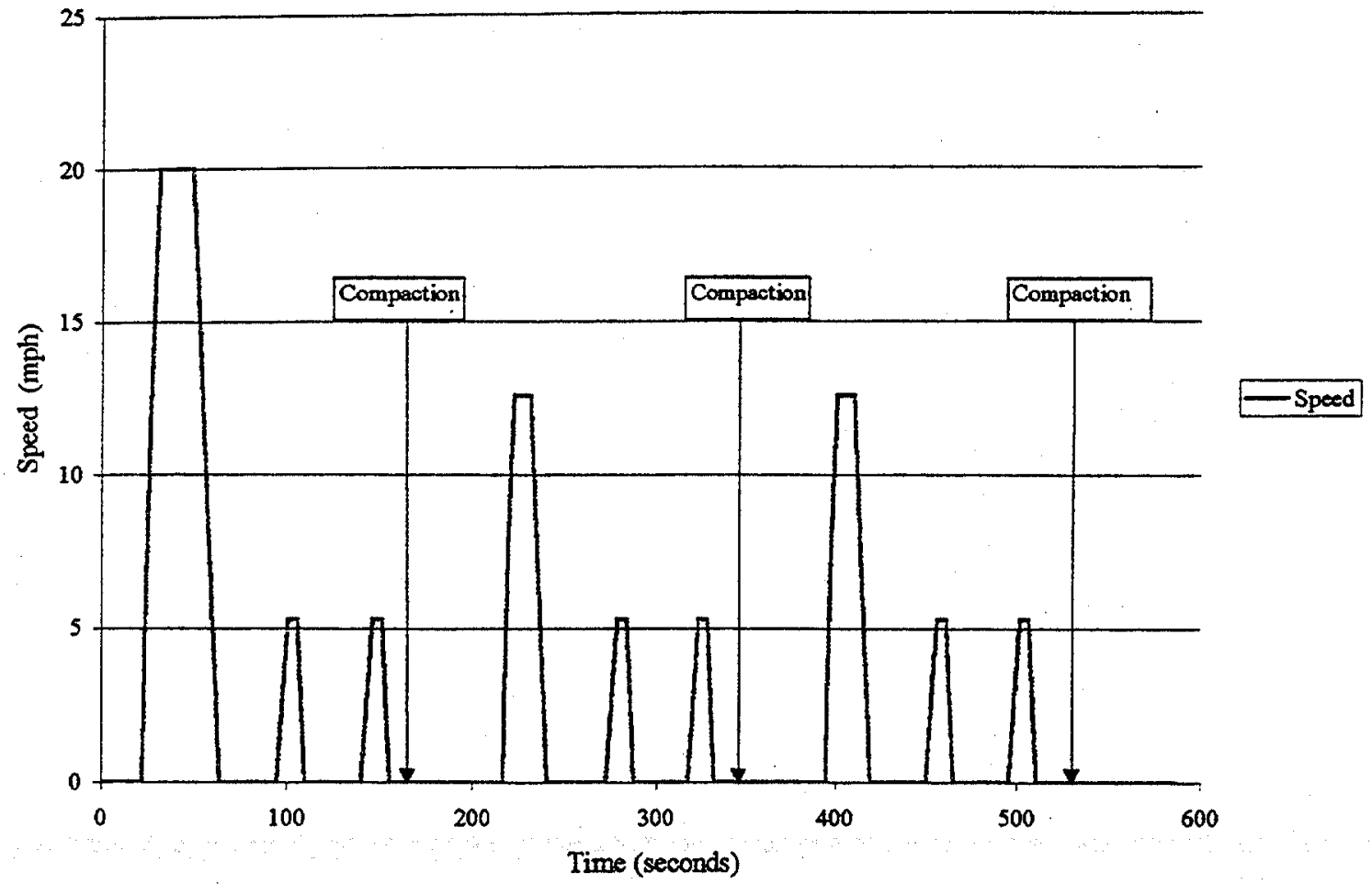

Figure 12: Emissions data, $\mathrm{CO}$ and NOx emissions in grams per gallon of fuel for comparison between the three engine types and two cycles types.

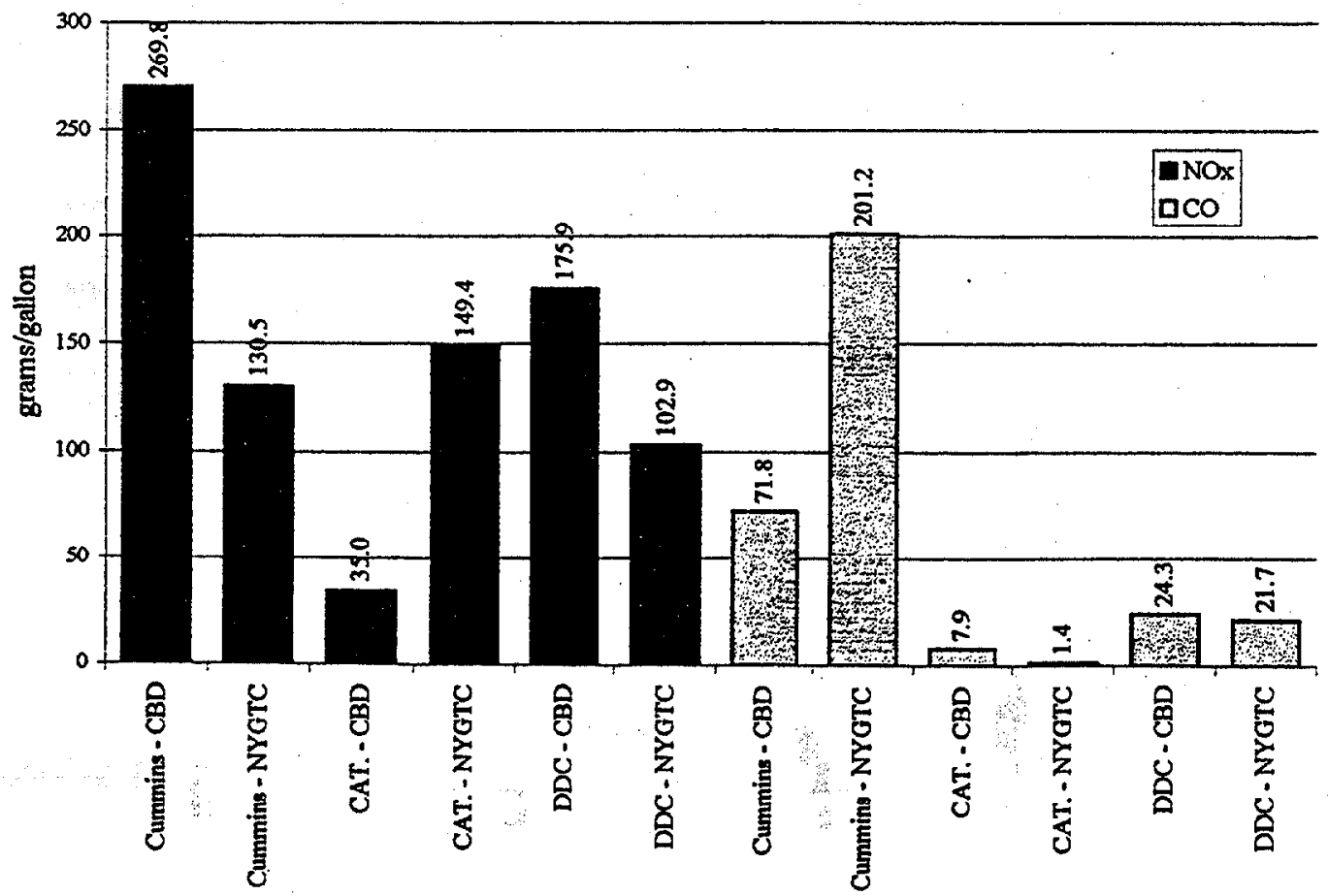

Engine Type and Cycle 